\title{
Investment in training and skills for innovation in entrepreneurial start-ups and incumbents: evidence from the United Kingdom
}

Article

Accepted Version

Belitski, M., Caiazza, R. and Rodionova, Y. (2020) Investment in training and skills for innovation in entrepreneurial start-ups and incumbents: evidence from the United Kingdom.

International Entrepreneurship and Management Journal, 16 (2). pp. 617-640. ISSN 1555-1938 doi:

https://doi.org/10.1007/s11365-019-00606-4 Available at https://centaur.reading.ac.uk/89025/

It is advisable to refer to the publisher's version if you intend to cite from the work. See Guidance on citing.

To link to this article DOI: http://dx.doi.org/10.1007/s11365-019-00606-4

Publisher: Springer

All outputs in CentAUR are protected by Intellectual Property Rights law, including copyright law. Copyright and IPR is retained by the creators or other copyright holders. Terms and conditions for use of this material are defined in the End User Agreement. 


\section{www.reading.ac.uk/centaur}

\section{CentAUR}

Central Archive at the University of Reading

Reading's research outputs online 
Investment in Training and Skills for Innovation in Entrepreneurial Start-ups and
Incumbents: Evidence from the United Kingdom

\begin{abstract}
Firms that aim to compete globally have to invest in knowledge and have to use knowledge returns to increase their competitive advantage. This paper extends our understanding of returns to knowledge investment by focusing on innovative training and skills in entrepreneurial organizations and incumbents, as well as the role of legal protection in further investment in knowledge.

Using novel innovation data for a panel of 4,049 firms in the UK, this paper estimates the training premium for the country's most innovative firms. Returns on training vary between start-ups and incumbents and during economically-constrained times. Specifically, the study highlights evidence for higher returns on training during times of crisis and lower returns before the crisis. In filling a gap in the calculation of returns to investment in knowledge creation within organization, the study advances our understanding on how entrepreneurial firms need to invest in training and skills to increase innovation outcomes.
\end{abstract}

Keywords: Innovation, Training, Skills, Entrepreneurship, Knowledge, United Kingdom

\title{
1. Introduction
}

Estimates of the returns to training and skills have always raised significant attention among academic researchers, patent offices and policy makers. As the number of patent applications has increased in Europe, Japan and the US (Kortum and Lerner 1999; EPO Annual Report 2003), knowledge expenditure as an asset has become an integral part of a firm's market value (Farooqui et al. 2011). Policy-makers have argued that the models estimating the value of patents, training and education using simple application or grant numbers and a bivariate choice of whether to invest in training and education (Giavanetti and Piga 2017) as an indication of innovativeness are no longer satisfactory. The models used by academics and scientists do not always comply with the availability of data or are unable to calculate even the approximate returns to training and skills from the available data sources. Moreover, most of the indicators used for innovative outcomes are skewed to the left of the normal distribution, which means that major parts of firms exhibiting zero innovation outputs. While there have been many studies on identifying the returns to training and skills (Eaton and Kortum 1999, Schankerman 1998; Arora et al. 2008) and even some working with the UK data on innovative companies and R\&D performers (Farooqui et al. 2011; Arora and Nandkumar 2011; Arora and Athreye 2012), the returns to innovative training have not yet been precisely identified.

At the same time there is another research gap between the effect of patent protection in inducing more training and education expenditure relevant for managerial policy. It is unclear what would happen to training expenditure if a company chose to protect its innovation by holding a patent (Markuerkiaga et al. 2016). Comparing both returns on patenting and training, we could shed some light on the substitutive or complimentary effects of patent and training returns in terms of revenues coming from new product sales to the market. The purpose of this study is thus to estimate the private returns to training and skills for UK firms and the incentives 
that patent protection offers for further investment in innovative training and education. This paper also focuses on how innovative training and innovation outcomes are affected by other factors when proxied by new product revenues (Acs et al. 2009).

This study makes an important contribution to the innovation literature by theoretically discussing and empirically testing the role that investment in knowledge and skills plays in the innovation process and new product commercialization. We estimate the model which brings together investment in knowledge, knowledge protection and innovation output, and distinguish the effects for small and incumbent firms. This approach extends prior research on training in innovative firms (Acemoglu, 1997; Giavannetti and Piga, 2017) by applying new data from new product revenues for a panel of 4,049 firms over the period 2002-2009. The model estimates patent premiums using the data on patent propensity for 4,049 UK innovators. This enables us to estimate the patent premium interval more precisely than previous studies have done (Arora and Athreye, 2012).

The results obtained are robust both across cross-sections and panel data estimation as well as when using different estimation techniques: the sign and significance of the coefficients do not change, although the value of the parameters becomes more precise. This has important implications for firm managers and policy-makers (Caiazza 2016a; Druker 2003The results hold while using different estimates for panel data: ordinary least squares, fixed and random effects, and iterative non-linear likelihood estimation. We also experimented with a new technique developed by Baltagi (2008) using the robust effects with instruments in a panel (Aguinis and Kraiger 2009). The paper also extends the managerial literature on intellectual capital by evidencing the relationship between knowledge investment, training and skills by integrating industry competitive context and firm size. In doing so, it reinforces the theoretical debate on sources of knowledge and knowing capabilities that can be used to give a company a competitive advantage (Nahapiet and Ghoshal 1998) and the role that protection of innovation plays in the innovation process (Arora et al. 2016)

The paper is organized as follows. Section 2 contains the literature review and the data overview on returns to training and the discussion. Section 3 describes this paper's research methods, discusses further econometric issues and describes the data. Section 4 discusses the results of the analysis and delivers research contributions. Section 5 discusses this paper's major findings and section 6 concludes.

\section{Theoretical Framework and Literature review}

\subsection{Previous research}

A firm's competitive advantage is based on its intellectual capital (Nahapiet and Ghoshal 1998) and how well its innovation has been protected (Arora et al. 2016). For this reason, firms that aim to compete globally have to invest in knowledge and have to use knowledge returns in training and skills to increase their competitive advantage. The question of returns on knowledge investment is thus very complex.

In addition, issues related to the legal and economic aspects of patents and the development of special skills through training and education programs are difficult to catalogue and categorize in questionnaires and surveys. Nevertheless, an attempt to systematically investigate the possible reasons for the differences in returns to patenting and knowledge expenditure has been made (Guerrero and Barraud-Didier 2004; Acs and Audretsch 1987b) as well as the role of concentration of skills and knowledge across cities and industrial clusters (Belitski and Desai 
2016a, 2016b).

The search for valid estimates of economic returns to training and skills received significant attention from economists, lawyers and policy makers during the 1990s and 2000s. Along with an increase in the relevance of other intangibles for firm performance and profitability, leading to new questions in innovation and strategy as to how patents and knowledge expenditure increase a firm's revenues and profits (Kortum and Lerner 1999; Arora et al. 2008, 2016). The overview of the literature which covers the early works in management and innovation literature related to returns to training is provided in Table B1 in Appendix B.

During the 2000s several cutting-edge research papers appeared. Greenhalgh and Rogers (2006) estimated the value of innovation and its link with competition, R\&D and intellectual property. This was the first study to use a new data set on the market valuations of UK companies and their knowledge expenditure including R\&D during 1989 - 2002 based on the technological classification originating from Pavitt (1984). The main result was that the valuation of R\&D varied substantially across UK sectors, while firms that receive on average only UK patents tend to have no significant market premiums (Caiazza 2015, Ojala and Heikkilä 2011; PerisOrtiz 2009).

In direct contrast, patenting through the European Patent Office does raise market value (Markuerkiaga et al. 2016). To explore further the reasons of low UK market premium on patenting, this paper links competitive conditions with the market valuation of innovation. Caiazza et al. (2015) find that finds that the sectors that are the most competitive ('science based' manufacturing) have the lowest market valuation of R\&D. Furthermore, firms with larger market shares tend to have higher R\&D valuations, as well as positive returns to UK patents (Audretsch et al 2008; Haber and Reichel 2007). This evidence supports Schumpeter's (1939) ideas by finding higher returns to innovation in less than perfect competitive markets. It also contradicts Arrow (1962) who argued that, with the existence of intellectual property rights, competitive market structures provide stronger incentives to innovate (Caiazza et al. 2016, Lloyd-Reason et al. 2005).

Follow-up research on returns to investment in knowledge was implemented by Tan and Batra (1997), Bulut and Moschini (2009), Acosta et al. (2009) and Artz et al. (2010). Bulut and Moschini (2009) study US universities which have increased their involvement in patenting and licensing activities through their own technology transfer offices. They found that only a few US universities are gaining high returns, while others are continuing with negative or zero returns (Caiazza and Stanton, 2016, Del Valle and Castillo 2009; Fullard 2007). The role of universities and external knowledge collaborators in facilitating entrepreneurial activity has been found to be important in both increasing returns to knowledge commercialization and learning new skills (Belitski et al. 2019a).

More recent research using UK data on innovators (Giovannetti and Piga 2017) has demonstrated that active involvement in innovation activities and knowledge transfers through active and passive cooperation increases innovation output and productivity. The breadth and depth of research on the role of training for innovation enables us to hypothesize: Hypothesis 1: Innovative training increases innovation output in both start-ups and incumbent firms.

The review of studies in Table A1 demonstrated that firms use various methods to protect their inventions, including patents and different forms of the first mover advantage (Cohen et al. 
1996; Caiazza 2016a). Patents serve to protect a firm's technological knowledge and embody an exclusion right. They also provide an incentive for firms to invest in innovation, knowledge and marketing activities (Greenhalgh and Rogers 2006; Caiazza 2017; Audretsch and Belitski, 2019). This is our link between the legal protection of innovation and further investment in training and education. As indicators, patents transmit information about a firm's technical knowledge and its intention to protect its inventions. A patent is a signal that a company is engaging in new product / process development, as new products / processes may require protection by patents. Similarly, patents can be used to identify firms planning to enter new product or geographic markets. This will subsequently affect knowledge expenditure including innovative training and research (Schankerman 1998).

In addition by Leiponen and Byma (2009) who examined the strategies small firms use for capturing the returns to investment in innovation, which turn out to be qualitatively different from those found in earlier studies of both small and large firms. The authors conclude that most of the small firms they reviewed use informal means of protection, such as speed to market or secrecy. These proved to be more important than patenting for small firms (Arellano and Bover 1995; Baldwin and Johnson 1995).

Only firms with university cooperation and large firms - typically R\&D intensive as well as knowledge-based small firms - were likely to identify patents as the most important method of protecting their innovation and securing returns to patenting. However, this does not mean that the returns to innovation for small firms are lower than those for large firms - it is an issue which needs to be further investigated (Belitski et al. 2019b; Audretsch and Caiazza 2016; Brem 2011 Correia and Petiz 2007). We hypothesize:

Hypothesis 2: Patent protection increases investment in innovative training for start-ups and incumbent firms.

\section{Data and Methodology}

\subsection{Identification Strategy}

Dependent variable. Commonly used indicators of innovation outcome based on Community Innovation Survey (CIS) data include percentage sales of products that are new to the market or to the firm or significantly improved compared to sales of other products. A review of the advantages and disadvantages of such indicators and some of the studies that employ them is provided by Arora and Athreye (2012). Their main advantages are that they provide a measure of the economic success of innovations (in terms of income which comes from sales of the innovative products); are applicable to all sectors; allow different types of innovations to be distinguished; and allow the definition of continuous variables, which contributes to the development of econometric analyses (Negassi 2004, Caiazza 2015). Their limitations are that they are sensitive to product life cycles and markets, which may differ in the context of competing companies (Kleinknecht et al. 2002; Frenz and Ietto-Gillies 2009).

For the robustness check to indicators: sales of products that are new to the market per

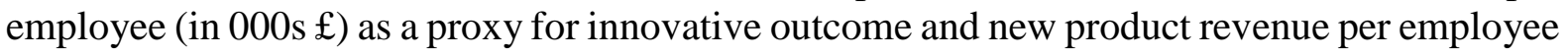
as a proxy for innovative performance will be explored. 


\subsection{Data description: Explanatory and control variables}

In recent years, many studies on innovation have used CIS-type data. CIS data is popular for analysing innovation because (i) it allows comparable indicators to analyse inter-country and intertemporal differences and develop robust empirical evidence, and (ii) surveys are usually conducted by national statistics offices which are experienced at data gathering, and which conduct extensive pre-testing and piloting to check interpretability, reliability and validity (Frenz and Ietto-Gillies 2009; Arora and Athreye 2012).

The dataset used in this paper is based on two independent, albeit mergeable, datasets: the CIS ${ }^{1}$ surveys conducted bi-annually by the Office of National Statistics (ONS UK) and the Business Survey Database (BSD) which we use to gain information on firm ownership, status (MNE or not MNE), the year of establishment and SIC sector activity (Caiazza et al. 2015, Caiazza and Stanton, 2016). The CIS provides detailed information on business characteristics, including names, addresses, postcodes, standard industrial classifications, employment and employee details, turnover, enterprise group links, and the turnover generated by new products. However, the survey only permits us to classify firms into innovators and non-innovators, and asks about types of aggregate innovative expenditures. It allows that firms produce the amount of expenditure in each innovation activity (intramural and extramural R\&D, Acquisition of external knowledge, Training, All forms of design, marketing expenditure, etc.) in a monetary value (£000s).

As regards the drivers of training, our paper employs standard controls as found in much of the literature (Galia and Legros 2004, Caiazza 2016a, 2016b), subject to their availability in our data. This includes firm size; the global nature of activities; cooperation with universities, public and government research bodies; adoption of a patent; industry dummies; and ownership type. Our survey also gives us an advantage of including the number of people educated to the degree level in the field of science in the firm's workforce, which is an original control variable (Branzei and Vertinsky 2006; Acs and Audretsch 1987a). The list of variables used in this study is in Table 1 while the descriptive statistics of all variables across all years of the survey can be seen in Table 2 and the correlation matrix is illustrated in Table 3.

\section{Table 1. Variables used in the study}

\begin{tabular}{|l|l|}
\hline Variable name & Measure description and construction \\
\hline $\begin{array}{l}\text { New product } \\
\text { revenue (NPR) } \\
\text { in } £ 000\end{array}$ & $\begin{array}{l}\text { NPR is obtained by multiplying firm's share of products introduced } \\
\text { that were new to firm's market by the firm's turnover. Measure } \\
\text { included was ln(1+NPR) }\end{array}$ \\
\hline $\begin{array}{l}\text { NPR per } \\
\text { employee }\end{array}$ & $\begin{array}{l}\text { NPR divided by the number of listed employees in £000. Measure } \\
\text { is reported as (1+NPR) / q2520 taken in logs }\end{array}$ \\
\hline Training (T) & $\begin{array}{l}\text { Training expenditure is company-financed training unit } \\
\text { expenditures in } £ 000 . \text { We transform measure in ln }(1+\mathrm{T})\end{array}$ \\
\hline Rivals & $\begin{array}{l}\text { Number of rivals in the industry calculated by 2 digit SIC (92) } \\
\text { sector taken in logs }\end{array}$ \\
\hline
\end{tabular}

\footnotetext{
${ }^{1}$ For more information on CIS and what these datasets contain see: http://nswebcopy/StatBase/Source.asp?vlnk=926\&More=Y
} 


\begin{tabular}{|c|c|}
\hline Global & $\begin{array}{l}\text { Dummy variable }=1 \text { if the enterprise sells goods and/or services } \\
\text { overseas (Other Europe and all other countries except the UK). }\end{array}$ \\
\hline Public & Dummy variable $=1$ if the enterprise is a publicly traded company. \\
\hline Foreign & $\begin{array}{l}\text { Dummy variable }=1 \text { if the parent firm is located abroad (USA or } \\
\text { other). }\end{array}$ \\
\hline Cooperation & $\begin{array}{l}\text { Dummy variable }=1 \text { if the co-operation partner (e.g. Universities or } \\
\text { other higher education institutions; Government or public research } \\
\text { institutes) is located locally/ regionally within the UK or a partner } \\
\text { is a UK national. Reporting unit level }\end{array}$ \\
\hline Patents & $\begin{array}{l}\text { Dummy variable }=1 \text { if the unit used patents to protect its innovation; } \\
\text { zero - if patent protection has not been used. Data is unavailable for } \\
\text { CIS6 due to changes in reporting the survey question. Reporting } \\
\text { unit level }\end{array}$ \\
\hline Scientists (S) & $\begin{array}{l}\text { Number of employees educated to degree level in science and } \\
\text { engineering. Measure included was } \ln (1+S)\end{array}$ \\
\hline Small firm & $\begin{array}{l}\text { Dummy variable }=1 \text { if the unit's number of employees less or equal } \\
50 \text {; zero - otherwise. Reporting unit level }\end{array}$ \\
\hline Large firm & $\begin{array}{l}\text { Dummy variable }=1 \text { if the unit's number of employees more or equal } \\
250 \text {; zero - otherwise. Reporting unit level }\end{array}$ \\
\hline Firm's capacity & $\begin{array}{l}\text { Reported the importance of increased capacity for production or } \\
\text { service provision for the product (good or service) and/or process } \\
\text { innovations. Four mutually exclusive responses ( } 0 \text { - Not used; } 1 \text { - } \\
\text { Low; } 2 \text { - Medium; } 3 \text { - High). }\end{array}$ \\
\hline Market info & $\begin{array}{l}\text { Reported the importance to enterprise the lack of information on } \\
\text { markets as a factor which constraints innovation activities. Four } \\
\text { mutually exclusive responses ( } 0 \text { - Not used; } 1 \text {-Low; } 2 \text { - Medium; } 3 \\
\text { - High). }\end{array}$ \\
\hline
\end{tabular}

Source: Department for Business, Innovation and Skills, Office for National Statistics, Northern Ireland. Department of Enterprise, Trade and Investment. (2018). UK Innovation Survey, 1994-2016: Secure Access. [data collection]. 6th Edition. UK Data Service. SN: 6699, http://doi.org/10.5255/UKDA-SN-6699-6 (hereinafter UKIS- UK Innovation survey) Office for National Statistics. (2017). Business Structure Database, 1997-2017: Secure Access. [data collection]. 9th Edition. UK Data Service. SN: 6697, http://doi.org/10.5255/UKDA-SN$\underline{6697-9}$ (hereinafter BSD- Business Structure Database) 
Table 2. Descriptive statistics

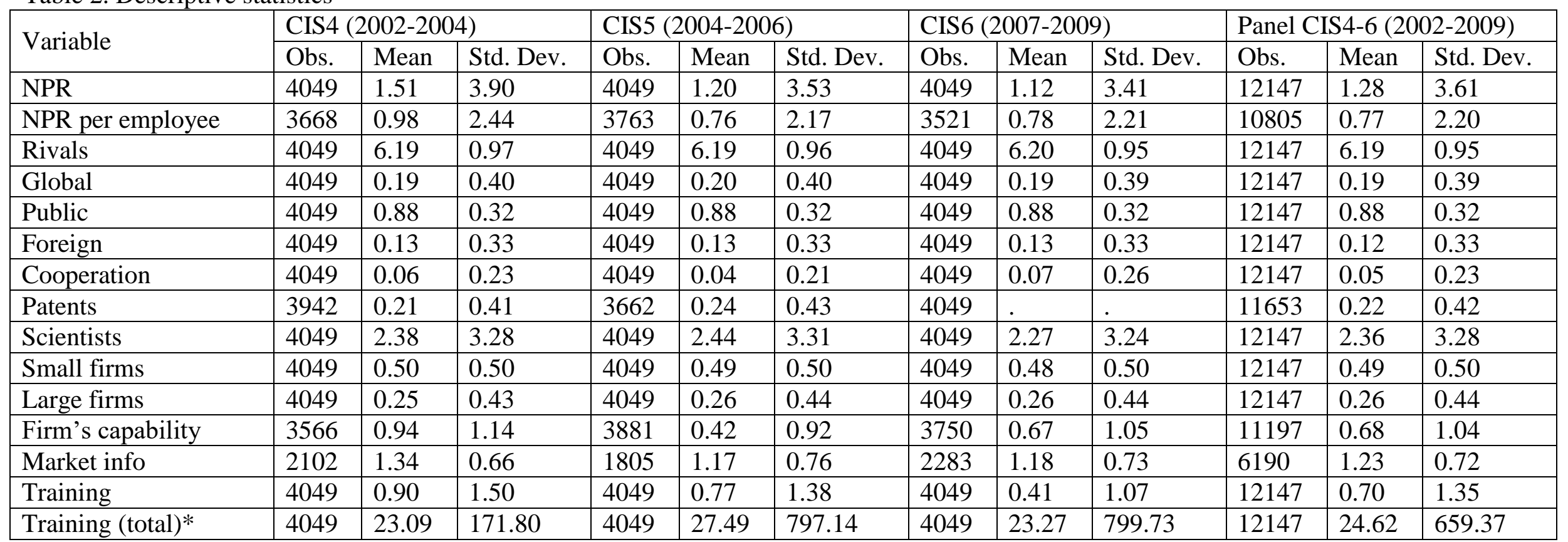

$*$ training and skills expenditure are taken in levels, 000s $£$

Source: UKIS- UK Innovation survey; BSD- Business Structure Database 
Table 4. Correlation matrix

\begin{tabular}{|c|c|c|c|c|c|c|c|c|c|c|c|c|c|}
\hline & NPR & $\begin{array}{l}\text { NPR per } \\
\text { employee* }\end{array}$ & Training & Rivals & Global & Public & Foreign & Cooperation & Patents & Scientists & Small firms & Large firms & $\begin{array}{l}\text { Firm's } \\
\text { capability }\end{array}$ \\
\hline $\begin{array}{l}\text { NPR per } \\
\text { Employee }\end{array}$ & $0.98 *$ & 1 & & & & & & & & & & & \\
\hline Training & $0.23 *$ & $0.20 *$ & 1 & & & & & & & & & & \\
\hline Rivals & $-0.12 *$ & $-0.13^{*}$ & $-0.03 *$ & 1 & & & & & & & & & \\
\hline Global & $0.22 *$ & $0.20 *$ & $0.15^{*}$ & $-0.21 *$ & 1 & & & & & & & & \\
\hline Public & $0.08 *$ & $0.07 *$ & $0.07 *$ & $-0.15 *$ & $0.11 *$ & 1 & & & & & & & \\
\hline Foreign & $0.08^{*}$ & $0.07 *$ & $0.13 *$ & $-0.15 *$ & $0.20 *$ & $0.13 *$ & 1 & & & & & & \\
\hline Cooperation & $0.25 *$ & $0.24 *$ & $0.20 *$ & $-0.10 *$ & $0.19 *$ & $0.03 *$ & $0.08 *$ & 1 & & & & & \\
\hline Patents & $0.24 *$ & $0.22 *$ & $0.22 *$ & $-0.13 *$ & $0.23 *$ & $0.10^{*}$ & $0.16^{*}$ & $0.13 *$ & 1 & & & & \\
\hline Scientists & $0.25^{*}$ & $0.20 *$ & $0.31 *$ & $-0.13 *$ & $0.31 *$ & $0.15^{*}$ & $0.25^{*}$ & $0.21 *$ & $0.24 *$ & 1 & & & \\
\hline Small firms & $-0.05^{*}$ & -0.01 & $-0.20^{*}$ & $-0.08 *$ & $-0.12 *$ & $-0.17 *$ & $-0.24 *$ & $-0.06^{*}$ & $-0.11^{*}$ & $-0.29 *$ & 1 & & \\
\hline Large firms & $0.06^{*}$ & $0.02 *$ & $0.21 *$ & $0.09 *$ & $0.06^{*}$ & $0.14 *$ & $0.27 *$ & $0.06^{*}$ & $0.11 *$ & $0.26^{*}$ & $-0.57 *$ & 1 & \\
\hline Firm's capability & $0.37 *$ & $0.36 *$ & $0.33 *$ & $-0.11 *$ & $0.21 *$ & $0.10^{*}$ & $0.09 *$ & $0.27 *$ & $0.18 *$ & $0.26 *$ & $-0.10^{*}$ & $0.09 *$ & 1 \\
\hline Market info & $0.13 *$ & $0.06 *$ & $0.14 *$ & $-0.04 *$ & $0.15 *$ & $0.03 *$ & $-0.02 *$ & $0.10 *$ & $0.12 *$ & $0.16^{*}$ & $0.03 *$ & $-0.05^{*}$ & $0.22 *$ \\
\hline
\end{tabular}

\section{Source: UKIS- UK Innovation survey; BSD- Business Structure Database}

Note: The variable NPR per employee as a proxy for the productivity of a new products / processes will not be used interchangeably with the level of innovation in our analysis given the correlation coefficient between the NPR and NPR per employee is approaching the unity. Moreover the sign of the relationship with the other independent variables is same. Additionally the confidence intervals of both variables are overlapping. Wald test on the equality of the correlation coefficients between the NPR and NPR per employee with the independent variables was not rejected at $1 \%$ significance level. This could also be seen by a simple eyeball test comparing the pairwise correlation coefficients in column 1 and column 2 of the Table. The results of the tests and regressions using both NPR and NPR per employee are available from authors upon request. 


\subsection{Empirical Model}

As the starting point of our analysis, we extend the theoretical model developed by Arora and Athreye (2012). While this was originally used to analyze the private returns to patenting and $R \& D$ incorporating the trade-offs of holding a patent postulated by Schankermann (1998), we apply it to investment in training and skills. From the CIS we first create a measure of the total revenue from new products $(\mathrm{y})$. Our model in the econometric form is as follows:

$y=P Q(1-\phi+\phi \delta) f(T)$

$\mathrm{y}=\mathrm{p}+\mathrm{q}+\ln (1-\phi+\delta \phi)+\ln (\mathrm{f}(\mathrm{T}))+\varepsilon_{\mathrm{i}}$

where $f(T)$ is thought of as an analogue of total factor productivity in a growth model taken as a residual. We assume $\mathrm{f}^{\prime}(\mathrm{T})>0$ which means that NPR is an increasing function of training. Now we can estimate (2) as a non-linear least squares (where $\phi$ is not known and $\delta$ is a parameter to be estimated). The econometric model of (2) becomes (3), where $\alpha=p+q+$ intercept. For simplicity we assume $f(T)=T$.

$\mathrm{y}_{\mathrm{i}}=\alpha+\mathrm{b}_{1} \ln \left(\mathrm{T}_{\mathrm{i}}\right)+\ln \left(1-\phi_{\mathrm{i}}+\delta \phi_{\mathrm{i}}\right)+\varepsilon_{\mathrm{i}}$

There are two issues. Firstly, (3) imposes a specific non-linear specification, albeit one that naturally follows. Secondly, T is endogenous. In particular, it will depend upon unobserved firm specific differences in price and quantity. Put differently, demand shocks (which affect $p$ and $q$ ) will also affect innovative training expenditure. This can easily be seen by writing $p=\mu_{p}+\varepsilon$, where $\mu_{\mathrm{p}}$ is the average (across firms) price and $\varepsilon$ is a firm-specific component of price. All else equal, if $\varepsilon$ is high, $\mathrm{T}$ will be higher too. The obvious way out is to find an instrument for T. A natural instrument for (3) is any variable that affects cost of inputs, provided it is independent of demand shocks. We have explored measures from the CIS, such as the importance of increased capacity for production or service provision to product (good or service) and/or process innovations introduced scaled (0-3); and the importance of knowledge factors as constraints to innovation activities or influencing a decision not to innovate, scaled (0-3). We also attempted to find the Arellano-Bond type instruments (Arellano and Bover 1995, Caiazza et al. 2017), i.e. the first lagged values of innovative training expenditure; however, the sample has considerably decreased increasing the selection bias.

Our econometric model based on panel data could be presented as follows:

$\mathrm{y}_{\mathrm{it}}=\alpha+\Sigma \mathrm{X}_{\mathrm{it}} \theta+\mathrm{B}_{1} \ln \left(\mathrm{T}_{\mathrm{it}}\right)+\mathrm{B}_{2} \mathrm{X}_{\mathrm{it}}+\mathrm{e}_{\mathrm{it}}$ 
$\mathrm{e}_{\mathrm{it}}=\mathrm{v}_{\mathrm{i}}+\mathrm{u}_{\mathrm{it}}$

where $\mathrm{i}$ denotes a reporting unit $(\mathrm{i}=1, \ldots, \mathrm{n})$ and $\mathrm{t}-$ the time period $(\mathrm{t}=1, . ., \mathrm{T}) ; \alpha$ is a vector of intercept terms, $\theta_{\text {it }}$ is a vector of unknown coefficients of the exogenous variables, $X_{\text {it }}$ is a vector of exogenous variables (controls); $\mathrm{T}_{\mathrm{it}}$ and $\mathrm{x}_{\mathrm{it}}$ are the variables of interest: training expenditure and patent protection of a firm $i$ in period $t$. The error term $e_{i t}$ consists of the unobserved individualspecific effects $v_{i}$, and the observation-specific errors $u_{i t}$.

\section{Results}

The results of the analysis are shown in Tables A1-A3 in Appendix A. Equation 1.10 explains the impact of holding a patent and of training expenditure on NPR, while the first stage equation 1.9 of 2SLS and IV Tobit estimates the incentives offered for training expenditure due to holding a patent and other factors.

Estimating the implied increment to new product revenue due to higher expenditure on training and education means we can speak about the marginal effect on NPR of innovative training and education expenditure. Existing estimates of training premiums as reported in the literature typically relate to an increase in operating profits (also value added, scrap rates and so on - please refer to Table 1) rather than to an increase in new product revenues. Put differently, this estimate combines both the direct and indirect effects from training expenditure on NPR analogically to returns to patenting and training (Holzer et al. 1993).

We find that the elasticity of the new product revenue with respect to training expenditure is within the range of $0.3-0.5 \%$ for the OLS estimates, in the range of 3-5\% for the 2SLS estimates, and varies from $15-36 \%$ for the Tobit estimates for different waves of the CIS.

When we estimate the same equations on the panel data, the corresponding elasticity of NPR to training expenditure is $0.25-0.32 \%$ for the linear panel data non-instrumented regressions (Pooled OLS, random and fixed effects, maximum-likelihood estimation), and $3.2-5.0 \%$ for the instrumented estimations (Davidsson and Honig 2003).

We thus note that our results (excluding Tobit results, where we do not perform the equivalent estimation on the panel data) are very robust and consistent both across cross-sections and the panel.

The elasticity is the lowest for the CIS4, and is the highest during the sample from the economically constrained period 2007-2009 - the data from CIS6 survey (Baum and Silverman 2004). The potential explanation is linked with the impact of an economic crisis, in the way that companies starting from the same level of training will intend to achieve higher returns to their input in various ways: improving the quality of services provided, putting additional pressure on workers, cutting other input costs, and so on. During the credit crunch years, workers are often expected to put in 
more effort for the same or even lower compensation, and fear of layoffs may increase their productivity. Furthermore, a consistently growing demand for new products given the lower level of inputs (including training expenditure) is going to increase the returns to training in terms of NPR. Given the same level of inputs (innovative training and education in our case) a company would attempt to achieve higher results during economically-constrained times and the more competitive external environment will drive up returns to inputs.

At the same time, the demand for innovative products in the UK may keep growing along with demand for basic products (i.e. technological gadgets could be an example here). In fact we expect the demand for innovative products to increase over time, which also explains the higher revenue on new products generated by innovative firm overtime, including the data from the economically constrained period (2007-2009). This explanation is consistent with the results obtained in Table A2 for the panel data estimates, when the Year dummy for CIS6 is positive and significant.

When splitting a sample into two in Table A3 we found that the training premium between startups and incumbents is respectively 2.8 and 3.3\%. This result is obtained using EC2SLS RE (Baltagi's EC2SLS random-effects estimator) as described in Baltagi (2008), which has proved to better fit the estimated model. A Likelihood-ratio test of Sigma $\mathrm{u}=0$ was rejected at $1 \%$ level in favour of random effects and the F-test of all $\mathrm{u}_{-} \mathrm{i}=0$ both confirms the presence of random effects in the model. Although we are not using Tobit estimation in panel data analysis, the consistency between the 2SLS estimations in Tables A1 and A2 is obvious. We are not attempting to calculate the training premium for start-ups and incumbents separately, although we can conclude that there are significant and positive returns, which are about 15-20\% higher for the incumbents ( $>10$ years).

\subsection{New product revenue and training expenditure}

The results for the instrumenting of innovative training expenditure (first stage estimates), presented in Table A1, give us an idea of the importance of the various drivers that explain training expenditure.

Consistent with most of the literature (Baldwin and Johnson 1995) relating to training and firm size, we find that small firm training expenditure is $19-39 \%$ less than the training expenditure of medium-sized firms, while large firms spend $13-58 \%$ more on training than medium sized firms (Hansson 2007).

The number of competitors has a positive impact on training expenditure, which suggests that firms may use their training policy as a strategy against their industry rivals.

Interestingly, cooperation between firms and universities/research institutes has a strong positive impact on training, the presence of such increasing training expenditure by $46-61 \%$.

Exports is negatively associated with training, however, this result is only significant for one 
survey wave (the CIS4).

The share of degree-educated scientists is positive and significant consistently across all three waves, which means that a $1 \%$ increase in the number of scientists results in $1 \%$ increase in the innovative training expenditure. This is the first study that employs a set of factors to predict innovative training expenditure (as opposed to the share of workers with higher education in general).

With regards to the variation of innovative training expenditure by industry, we find that training expenditure tends to be $45-53 \%$ higher in the computer \& electronic equipment industry, 40-61\% higher in the production of instruments, and $30 \%$ in the transportation industry. However, the latter result is obtained for CIS4 data only (Florin et al. 2003).

Finally, we found that the "Reported the importance of increased capacity for production or service provision for the product (good or service) and/or process innovations" increases training expenditure by $16-31 \%$ for a unit increase in the indicator and is significant for all three waves of data.

Firm's "reported the importance to enterprise the lack of information on markets as a factor which constraints innovation activities has a positive effect on training, increasing it by $5 \%$ for a unit increase in the indicator.

As pointed out in Section 4.3, patent adoption was not found to have any significant effect on the innovative training expenditure.

\section{Discussion}

Our study develops the methodology (a model) and quantifies additional revenue coming from sales of new products due to investment in innovative training by firms and the fact that a firm holds a patent to protect its innovation. The result is estimated for innovative companies in the UK and the model could be easily applied to the other micro-level studies using various proxies for innovative outcomes and knowledge expenditures. This is our contribution to the literature on returns to patenting and training.

Our estimates show that the returns on investment in innovative training are generally lower than those found in previous studies researching the impact of training on firm performance (Bartel, 1994; 2000; Giavanetti and Piga, 2017). The results obtained via the instrumented panel data technique established the returns to training were on average about 3.7-3.8\% overall. They were a further $2.8 \%$ for start-ups and 3.3\% for incumbents over the period 2002-2009. More sophisticated Tobit estimations quantified the returns on training as between $15 \%$ and $36 \%$ over the period 20022009 using the cross-section technique. Moreover, we measure the returns to innovative training using NPR, which includes only the increase in the company's innovative outcomes. We cannot 
expect them to be as high as the corresponding return to training using other more general measures (total sales, overall labour productivity, value added).

Using both cross-section and panel data estimation we show that there are positive returns to training and patenting in terms of new product sales. In addition, this study enables us to achieve more precise measures of return on investment in training than the previous studies have demonstrated to be able to capture (Giovannetti and Piga, 2017).

In particular panel data estimation enables us to control for both fixed and random effects and justify the results obtained using cross-section analyses for three periods (CIS4-6). The only exception Cassidy et al. (2005) found in their research on returns to training is cross-sectional, with noise coming from previous periods and potentially affecting innovative outcomes. As noted before, we used instrument training which has proven to be endogenous in our model (Giovannetti and Piga, 2017; Herron and Robinson 1993; Negassi 2004). This gives us an improvement in efficiency; while a number of previous studies failed to find a significant link between training and performance, since they did not use instrumenting, this could therefore explain such an outcome. On the contrary, our results are robust and significant across all three cross-sections and in the panel data with fixed and random effects (Unger et al. 2011).

Dealing with the endogeneity of training expenditure allowed us to estimate the main determinants of training, and also to test $\mathrm{H} 2$ on the positive increments of patent protection to the investment in knowledge (training and education). Rejecting $\mathrm{H} 2$ in the Table A1 has an important interpretation firstly for policy makers and government agencies. The UK government's Department of Business, Innovation and Skills and the UK intellectual patent office may be interested in the result that there will not be any increase in knowledge expenditure for the firm once the patent protection is in force. In fact, government agencies interested in stimulating training and education expenditure by UK innovators should encourage inventors to consider instruments other than patents and not to rely on the high knowledge intensity once a patent is issued.

Legal protection by patents neither encourages nor discourages knowledge expenditure. We would like to advise policy-makers to initiate projects that encourage cooperation between firms and universities or other higher educational institutions, as well as government or public research institutes located locally/regionally within the UK. This recommendation could be developed from the results of the estimation in Table A1 (first stage).

Additionally, helping companies to recruit and educate potential employees with degrees in science and engineering will push up the knowledge expenditure and also increase the innovative outcomes. Both of the policy instruments could be considered priorities while developing skill and innovation policies for the UK's active innovation performers (Van der Sluis et al. 2005). 


\section{Conclusions}

This study aimed to assess the returns to innovative training in the most innovative firms in the UK. We exploited the availability of matched micro-data to assess returns to training and skills using a structural model of innovation output function. In this model, innovations depend upon the extent of knowledge investment by the firm and firm characteristics, which we found important to the innovation process from the previous literature. We extended the model developed by Arora and Athreye (2012), allowing for training and skills investment to respond to the higher profitability from innovation due to other factors, including firm ownership, absorptive capacity and legal protection of innovation. The model we developed thus allows for the estimation of training premiums, and further allows us to measure the incentive that other factors provide for training and skills expenditures.

The main limitation of this study is the anonymous nature of the UK Innovation survey. No additional sources for information on external partners could be added to the database, which could have been used to supplement the data, in particular regarding the lengths and persistence of training. In addition, we did not analyze all the different ways in which patenting might affect innovation. However, we were able to analyze the income and sales returns due to the existence/nonexistence of patent protection controlling for other firm-specific characteristics.

In order to keep up with modern challenges in innovation, this paper calls for the formulation of an efficient policy on intellectual property right protection and knowledge investment on the basis of the results obtained in the study. Further research will focus on specific industrial sectors used as controls in the model and for different levels of eco-innovation effectiveness. The relevant questions could be: "Are the returns to patenting and innovative training different for firms of various sizes, location and industries? Are the returns to patenting higher for green innovators and social entrepreneurs? What is the patent propensity of UK innovators by industry, firm size and age? How could patent propensity impact final innovative outcomes and a firm's innovative performance? Is there a link between patent protection and investment in knowledge expenditure by firm size, firm age, location and type of industry? This will help formulate policies for providing incentives to invest in more training and education by firms. This study is a starting point for further research on returns to knowledge expenditure on training and patent protection of UK innovators.

\section{References}


Acemoglu D. (1997) Training and Innovation in an Imperfect Labour Market'. Review of Economic Studies, 64, 445-464.

Acosta, P. A., Lartey, E. K., \& Mandelman, F. S. (2009). Remittances and the Dutch disease. Journal of international economics, 79(1), 102-116.

Acs J.Z. \& Audretsch D.B. (1987a). Innovation, Market Structure, and Firm Size'. The Review of Economics and Statistics, 69(4), 567-574.

Acs J.Z. \& Audretsch D.B. (1987b) Innovation in Large and Small Firms. Economic letters 23(1), $109-112$.

Acs Z.J., Audretsch D.B., Braunerhjelm P. \& Carlsson B. (2009). The knowledge spillover theory of entrepreneurship. Small Business Economics, 32, 15-30.

Aguinis H. \& Kraiger, K. (2009) Benefits of training and development for individuals and teams, organizations, and society. Annual Review of Psychology, 60, 451-474.

Arellano, M., \& Bover, O. (1995). Another look at the instrumental variable estimation of errorcomponents models. Journal of econometrics, 68(1), 29-51.

Arora, A., \& Nandkumar, A. (2011). Cash-out or flameout! Opportunity cost and entrepreneurial strategy: Theory, and evidence from the information security industry. Management Science, 57(10), 1844-1860.

Arora, A. \& Athreye, S. (2012). Patent Incentives - Return to Patenting and the Inducement for Research \& Development (R\&D). The Intellectual Property Office. ISBN: 978-1-908908-26-1.

Arora, A., Athreye, S., \& Huang, C. (2016). The paradox of openness revisited: Collaborative innovation and patenting by UK innovators. Research Policy, 45(7), 1352-1361.

Arora, A., Ceccagnoli, M., \& Cohen, W. M. (2008). R\&D and the patent premium. International journal of industrial organization, 26(5), 1153-1179.

Arrow, K.J. (1962). The economic Implications of Learning by Doing. Review of Economic Studies, 29, 155-173.

Artz K.W., Norman P.M., Hatfield, D.E. \& Cardinal L.B. (2010). A longitudinal study of the impact of R\&D, patents, and product innovation on firm performance. Journal of Product Innovation Management, 27(5), 725-740.

Audretsch D.B., Bönte, W. \& Keilbach M. (2008). Entrepreneurship capital and its impact on knowledge diffusion and economic performance. Journal of Business Venturing, 23, 687-698.

Audretsch D.B. \& Caiazza R. (2016). Technology transfer and entrepreneurship: Cross-national analysis, The Journal of Technology Transfer, 41(6), 1247-1259.

Audretsch, D. B., \& Belitski, M. (2019). The limits to collaboration across four of the most innovative UK industries. British Journal of Management.

Baldwin J.R. \& Johnson J. (1995) Human capital development and innovation: The case of training 
in small and medium-sized firms. Statistics Canada: Working Paper No. 74.

Baltagi H.B. (2008). Econometrics. Syracuse: Springer.

Cohen, W., Nelson, R., \& Walsh, J. (1996). Links and impacts: New survey results on the influence of University research on industrial R\&D. Pittsburgh, Penn.: Department of Social and Decision Sciences, Carnegie Mellon University.

Barrett, A., \& O'Connell, P. J. (2001). Does training generally work? The returns to in-company training. ILR Review, 54(3), 647-662.

Bartel A.P. (1994) Productivity gains from the implementation of employee training programs. Industrial Relations, 33, 411-425.

Bartel A.P. (2000) Measuring the Employer's Return on Investments in Training: Evidence from the Literature. Industrial Relations: Journal of Economy and Society, 39(3),502-524.

Bassi L.J. (1984). Estimating the effect of training programs with non-random selection. Review of Economics and Statistics, 66(1),36-43.

Baum J.A.C. \& Silverman B.S. (2004). Picking winners or building them? Alliance, intellectual, and human capital as selection criteria in venture financing and performance of biotechnology startups. Journal of Business Venturing, 19, 411-436.

Belitski, M., \& Desai, S. (2016a). Creativity, entrepreneurship and economic development: citylevel evidence on creativity spillover of entrepreneurship. The Journal of Technology Transfer, 41(6), 1354-1376.

Belitski, M., \& Desai, S. (2016b). What drives ICT clustering in European cities?. The Journal of Technology Transfer, 41(3), 430-450.

Belitski, M., Aginskaja, A., \& Marozau, R. (2019a). Commercializing university research in transition economies: Technology transfer offices or direct industrial funding? Research Policy, 48(3), 601-615.

Belitski, M., Caiazza, R., \& Lehmann, E. E. (2019b). Knowledge frontiers and boundaries in entrepreneurship research. Small Business Economics, 1-11.

Bishop J.H. (1991) On-the-job Training of New Hires. In: Stern, D., Ritzen J.M., (Eds.), Market Failure in Training? New York: Springer-Verlag.

Black S.E. \& Lynch L.M. (1996). Human-capital Investments and Productivity. American Economic Review Papers and Proceedings, 86(2), 263-267.

Black S.E. \& Lynch L.M. (2001). How to Compete: The Impact of Workplace Practices and Information Technology on Productivity. Review of Economics and Statistics, 83(3): 434-445.

Branzei O. \& Vertinsky I. (2006) Strategic pathways to product innovation capabilities in SMEs. Journal of Business Venturing, 21, 75-105.

Brem, A. (2011). Linking innovation and entrepreneurship-literature overview and introduction 
of a process-oriented framework. International Journal of Entrepreneurship and Innovation Management, 14(1), 6-35.

Bulut, H., \& Moschini, G. (2009). US universities' net returns from patenting and licensing: A quantile regression analysis. Economics of Innovation and New Technology, 18(2), 123-137.

Caiazza R. (2015) Explaining innovation in mature industries: Evidences from Italian SMEs, Technology Analysis \& Strategic Management, 27(8), 975-985

Caiazza R. (2016a) A cross-national analysis of policies effecting innovation diffusion, The Journal of Technology Transfer, 41 (6) 1406-1419,

Caiazza R. (2016b), Internationalization of SMEs in high potential markets, Trends in Food Science \& Technology, 58(1), 127-132.

Caiazza R. (2017). Innovation for sustainability: A conceptual framework, Journal of Management Development, 36(1), 37-47.

Caiazza R., Foss N., Volpe T. (2016). What we do know and what we need to know about knowledge in the growth process, Journal of Organizational Effectiveness: People and Performance, 3(2), 191-203.

Caiazza R., Richardson A., \& Audretsch D.B. (2015). Knowledge effects on competitiveness: From firms to regional advantage, The Journal of Technology Transfer, 40(6) 899-909.

Caiazza R., Shane S. \& Ferrara G. (2017). Entrepreneurial university: Geographical and strategic differences around the world, Journal of Management Development, 36(2), 142-145.

Caiazza, R., \& Stanton, J. (2016). The effect of strategic partnership on innovation: An empirical analysis, Trends in Food Science \& Technology, 54(1), 208-212.

Cassidy M., Görg H. \& Strobl E. (2005). Knowledge accumulation and productivity: Evidence from plant level data for Ireland. Scottish Journal of Political Economy, 52(3), 344-358.

Correia, I. M., \& Petiz, O. (2007). Firms and universities-do spillovers enhance firm's performance?. International Entrepreneurship and Management Journal, 3(2), 145-157.

Davidsson P. \& Honig B. (2003) The role of social and human capital among nascent entrepreneurs. Journal of Business Venturing, 18, 301-331.

Del Valle, I. D., \& Castillo, M. A. S. (2009). Human capital and sustainable competitive advantage: an analysis of the relationship between training and performance. International Entrepreneurship and Management Journal, 5(2), 139-163.

Druker, J. (2003). Enabling business innovation: government policy in the UK. International Journal of Entrepreneurship and Innovation Management, 3(3), 211-226.

Eaton, J., Kortum, S. (1999). International technology diffusion: Theory and measurement. International Economic Review, 40(3), 537-570.

EPO Annual Report (2003). http://annual-report.european-patent-office.org/2003/ 
Farooqui, S., Goodridge, P. \& Haskel, J. (2011). The Role of Intellectual Property Rights in the UK Market Sector, Newport, Intellectual Property Office.

Florin J., Lubatkin M. \& Schulze W. (2003) A social capital model of high growth ventures. Academy of Management Journal, 46(3), 374-384.

Frenz, M., \& Ietto-Gillies, G. (2009). The impact on innovation performance of different sources of knowledge: Evidence from the UK Community Innovation Survey. Research Policy, 38(7), 1125-1135.

Fullard, F. (2007). A model to evaluate the effectiveness of enterprise training programmes. International Entrepreneurship and Management Journal, 3(3), 263-276.

Galia, F., \& Legros, D. (2004). Complementarities between obstacles to innovation: evidence from France. Research policy, 33(8), 1185-1199.

Giovannetti, E., \& Piga, C. A. (2017). The contrasting effects of active and passive cooperation on innovation and productivity: Evidence from British local innovation networks. International Journal of Production Economics, 187, 102-112.

Greenhalgh, C., \& Rogers, M. (2006). The value of innovation: The interaction of competition, R\&D and IP. Research Policy, 35(4), 562-580.

Guerrero, S. \& Barraud-Didier, V. (2004) High-involvement practices and performance of French firms. Int. J. Human Resources Management, 15, 1408-1423.

Haber S. \& Reichel A. (2007). The cumulative nature of the entrepreneurial process: the contribution of human capital, planning and environmental resources to small venture performance. Journal Business Venturing, 22,119-145.

Hansson B. (2007) Company-based determinants of training and the impact of training on company performance. Results from an international HRM survey. Personnel Review, 36(2), 311331.

Herron, L. \& Robinson, R.B. (1993) A structural model of the effects of entrepreneurial characteristics on venture performance, Journal Business Venturing, 8(3), 281-294.

Holzer, H.J., Block, R.N., Cheatham, M. \& Knott, J.H. (1993). Are training subsidies for firms effective? The Michigan experience. Industrial and Labor Relations Review, 46(4), 625-636.

Huselid, M.A. (1995) The impact of human resource management practices on turnover, productivity, and corporate financial performance. The Academy of Management Journal, 38(3) 635-672.

Kleinknecht, A., Van Montfort, K., \& Brouwer, E. (2002). The non-trivial choice between innovation indicators. Economics of Innovation and new technology, 11(2), 109-121.

Kortum, S. \& Lerner, J. (1999). What is Behind the Recent Surge in Patenting, Research Policy, $28,1-22$. 
Leiponen, A., \& Byma, J. (2009). If you cannot block, you better run: Small firms, cooperative innovation, and appropriation strategies. Research Policy, 38(9), 1478-1488.

Lloyd-Reason, L., Damyanov, A., Nicolescu, O., \& Wall, S. (2005). Internationalisation process, SMEs and transitional economies: a four-country perspective. International Journal of Entrepreneurship and Innovation Management, 5(3-4), 206-226.

Markuerkiaga L., Caiazza, R., Igartua, J.I. \& Errasti N. (2016). Factors fostering students' spin-off firm formation: An empirical comparative study of universities from North and South Europe, Journal of Management Development, 35(6), 814-846.

Nahapiet, J., \& Ghoshal, S. (1998). Social capital, intellectual capital, and the organizational advantage. Academy of management review, 23(2), 242-266.

Negassi, S. (2004). R\&D co-operation and innovation a microeconometric study on French firms. Research policy, 33(3), 365-384.

Ojala, A., \& Heikkilä, J. (2011). Entrepreneurship training for new ventures. International Entrepreneurship and Management Journal, 7(3), 297-310.

Pavitt, K. (1984). Sectoral patterns of technical change: towards a taxonomy and a theory. Research policy, 13(6), 343-373.

Peris-Ortiz, M. (2009). An analytical model for human resource management as an enabler of organizational renewal: a framework for corporate entrepreneurship. International Entrepreneurship and Management Journal, 5(4), 461.

Schankerman, M. (1998). How valuable is patent protection? Estimates by technology field. the RAND Journal of Economics, 77-107.

Schumpeter, J.A. (1939). Business Cycles. A Theoretical, Historical and Statistical Analysis of the Capitalist Process. New York: Mc Graw Hill.

Tan, H., \& Batra, G. (1997). Technology and firm size-wage differentials in Colombia, Mexico, and Taiwan (China). The World Bank Economic Review, 11(1), 59-83.

Thornhill S. (2006). Knowledge, innovation and firm performance in high- and low-technology regimes. Journal of Business Venturing, 21(5), 687-703.

Unger J.M., Rauch A., Frese M., \& Rosenbusch N. (2011) Human capital and entrepreneurial success: A meta-analytical review. Journal Business Venturing, 26, 341-358.

Van der Sluis J., Van Praag C.M. \& Vijverberg W. (2005) Entrepreneurship, selection and performance: a meta-analysis of the role of education. World Bank Economic Review, 19(2), 225261. 


\section{Appendix A}

Table A1: Training premium equation: Model 1 (cross-section estimation by CIS)

\begin{tabular}{|c|c|c|c|c|c|c|c|c|c|}
\hline Dep. Var.: NPR in 000s $£, \log$ & \multicolumn{3}{|c|}{ CIS4 (2002-2004) } & \multicolumn{3}{|c|}{ CIS5 (2004-2006) } & \multicolumn{3}{|c|}{ CIS6 (2007-2009) } \\
\hline Estimation method & OLS & 2 SLS & IV Tobit & OLS & $2 S L S$ & IV Tobit & OLS & 2SLS & IV Tobit \\
\hline Training & $\begin{array}{l}0.28 * * * \\
(0.05)\end{array}$ & $\begin{array}{l}3.45 * * * \\
(0.58)\end{array}$ & $\begin{array}{l}20.6^{* * * *} \\
(3.43)\end{array}$ & $\begin{array}{l}0.33^{* * * *} \\
(0.06)\end{array}$ & $\begin{array}{l}3.22 * * * \\
(0.47)\end{array}$ & $\begin{array}{l}14.8^{* * * *} \\
(2.29)\end{array}$ & $\begin{array}{l}0.50 \text { *** } \\
(0.09)\end{array}$ & $\begin{array}{l}5.14 * * * \\
(0.74)\end{array}$ & $\begin{array}{l}36.4 * * * \\
(5.51)\end{array}$ \\
\hline Rivals & $\begin{array}{l}-0.14 * * \\
(0.06)\end{array}$ & $\begin{array}{l}-0.50 * * * \\
(0.18)\end{array}$ & $\begin{array}{l}-2.77 * * * \\
(0.98)\end{array}$ & $\begin{array}{l}-0.18 * * * \\
(0.07)\end{array}$ & $\begin{array}{l}-0.51 * * * \\
(0.18)\end{array}$ & $\begin{array}{l}-2.52 * * * \\
(0.88)\end{array}$ & $\begin{array}{l}-0.17 * * * \\
(0.06)\end{array}$ & $\begin{array}{l}-0.15 \\
(0.15)\end{array}$ & $\begin{array}{l}-0.78 \\
(1.09)\end{array}$ \\
\hline Global & $\begin{array}{l}0.60 \text { **** } \\
(0.20)\end{array}$ & $\begin{array}{l}1.20 * * * \\
(0.41)\end{array}$ & $\begin{array}{l}\text { 6.18*** } \\
(2.23)\end{array}$ & $\begin{array}{l}0.84 * * * \\
(0.18)\end{array}$ & $\begin{array}{l}1.12^{* * * *} \\
(0.39)\end{array}$ & $\begin{array}{l}4.64 * * \\
(1.84)\end{array}$ & $\begin{array}{l}1.02 * * * \\
(0.18)\end{array}$ & $\begin{array}{l}0.34 \\
(0.37)\end{array}$ & $\begin{array}{l}1.49 \\
(2.57)\end{array}$ \\
\hline Public & $\begin{array}{l}0.29 * * \\
(0.12)\end{array}$ & $\begin{array}{l}0.81 \\
(0.56)\end{array}$ & $\begin{array}{l}6.84 * * \\
(3.47)\end{array}$ & $\begin{array}{l}0.31^{* * *} \\
(0.12)\end{array}$ & $\begin{array}{l}1.00 \\
(0.63)\end{array}$ & $\begin{array}{l}5.55^{*} \\
(3.33)\end{array}$ & $\begin{array}{l}0.23^{* *} \\
(0.11)\end{array}$ & $\begin{array}{l}0.01 \\
(0.49)\end{array}$ & $\begin{array}{l}-0.69 \\
(3.63)\end{array}$ \\
\hline Foreign & $\begin{array}{l}-0.43 \\
(0.27)\end{array}$ & $\begin{array}{l}-0.91 \\
(0.57)\end{array}$ & $\begin{array}{l}-5.02 \\
(3.08)\end{array}$ & $\begin{array}{l}-0.40 \\
(0.27)\end{array}$ & $\begin{array}{l}-0.40 \\
(0.57)\end{array}$ & $\begin{array}{l}-2.37 \\
(2.79)\end{array}$ & $\begin{array}{l}0.033 \\
(0.24)\end{array}$ & $\begin{array}{l}0.81^{*} \\
(0.49)\end{array}$ & $\begin{array}{l}6.20^{*} \\
(3.45)\end{array}$ \\
\hline Cooperation & $\begin{array}{l}2.36 * * * * \\
(0.39)\end{array}$ & $\begin{array}{l}0.60 \\
(0.65)\end{array}$ & $\begin{array}{l}-3.45 \\
(3.45)\end{array}$ & $\begin{array}{l}2.85 * * * \\
(0.46)\end{array}$ & $\begin{array}{l}0.63 \\
(0.69)\end{array}$ & $\begin{array}{l}-1.25 \\
(3.01)\end{array}$ & $\begin{array}{l}2.13 * * * * \\
(0.34)\end{array}$ & $\begin{array}{l}-1.33^{*} \\
(0.72)\end{array}$ & $\begin{array}{l}-15.9 \text { **** } \\
(4.98)\end{array}$ \\
\hline Patents & $\begin{array}{l}2.08^{* * * *} \\
(0.21)\end{array}$ & $\begin{array}{l}1.62^{\text {**** }} \\
(0.35) \\
\end{array}$ & $\begin{array}{l}6.43^{\text {**** }} \\
(1.93) \\
\end{array}$ & $\begin{array}{l}1.24 * * * \\
(0.18)\end{array}$ & $\begin{array}{l}0.59^{*} \\
(0.35)\end{array}$ & $\begin{array}{l}2.94^{*} \\
(1.68)\end{array}$ & & & \\
\hline Scientists & $\begin{array}{l}0.11 \text { *** } \\
(0.02)\end{array}$ & $\begin{array}{l}-0.16^{* * *} \\
(0.08)\end{array}$ & $\begin{array}{l}-1.27 \text { *** } \\
(0.44)\end{array}$ & $\begin{array}{l}0.11^{*} * * \\
(0.02)\end{array}$ & $\begin{array}{l}-0.080 \\
(0.06)\end{array}$ & $\begin{array}{l}-0.32 \\
(0.31)\end{array}$ & $\begin{array}{l}0.14 \text { *** } \\
(0.02)\end{array}$ & $\begin{array}{l}-0.25 \text { *** } \\
(0.08)\end{array}$ & $\begin{array}{l}-1.97 \text { *** } \\
(0.57)\end{array}$ \\
\hline Small firm & $\begin{array}{l}0.15 \\
(0.13)\end{array}$ & $\begin{array}{l}1.24 * * * \\
(0.42)\end{array}$ & $\begin{array}{l}7.86^{* * * *} \\
(2.39)\end{array}$ & $\begin{array}{l}0.39 * * * \\
(0.13)\end{array}$ & $\begin{array}{l}1.65^{* * * *} \\
(0.44)\end{array}$ & $\begin{array}{l}8.99 \text { *** } \\
(2.19)\end{array}$ & $\begin{array}{l}0.31 \text { *** } \\
(0.12)\end{array}$ & $\begin{array}{l}1.15^{* * * *} \\
(0.36)\end{array}$ & $\begin{array}{l}9.05 \text { *** } \\
(2.60)\end{array}$ \\
\hline Large firm & $\begin{array}{l}0.11 \\
(0.19)\end{array}$ & $\begin{array}{l}-1.99 * * * \\
(0.57)\end{array}$ & $\begin{array}{l}-12.8^{* * * *} \\
(3.25)\end{array}$ & $\begin{array}{l}0.11 \\
(0.18)\end{array}$ & $\begin{array}{l}-1.31 * * \\
(0.52)\end{array}$ & $\begin{array}{l}-7.02 * * * \\
(2.50)\end{array}$ & $\begin{array}{l}-0.13 \\
(0.15)\end{array}$ & $\begin{array}{l}-0.57 \\
(0.38)\end{array}$ & $\begin{array}{l}-6.12 * * \\
(2.78)\end{array}$ \\
\hline Constant & $\begin{array}{l}0.89^{*} \\
(0.47)\end{array}$ & $\begin{array}{l}-0.13 \\
(1.31)\end{array}$ & $\begin{array}{l}-27.3^{* * * *} \\
(7.51)\end{array}$ & $\begin{array}{l}0.79 \\
(0.49)\end{array}$ & $\begin{array}{l}-0.33 \\
(1.42)\end{array}$ & $\begin{array}{l}-24.9 * * * \\
(7.03)\end{array}$ & $\begin{array}{l}0.98^{* * *} \\
(0.44)\end{array}$ & $\begin{array}{l}-0.025 \\
(1.17)\end{array}$ & $\begin{array}{l}-29.5 * * * * \\
(8.57)\end{array}$ \\
\hline Industry 2 digit SIC controls & Yes & Yes & Yes & Yes & Yes & Yes & Yes & Yes & Yes \\
\hline Obs. & 3942 & 1779 & 1779 & 3662 & 1413 & 1413 & 4049 & 2152 & 2152 \\
\hline R-square & 0.170 & -0.976 & & 0.164 & -0.734 & & 0.164 & -1.406 & \\
\hline F statistics & 26.24 & 10.45 & & 20.69 & 9.36 & & 20.33 & 10.85 & \\
\hline Sargan J-stat & & 0.001 & & & 0.028 & & & 0.049 & \\
\hline Sargan $\mathrm{J}$ stat. p-value & & 0.96 & & & 0.86 & & & 0.82 & \\
\hline Anderson-Rubin chi-sq & & 86.83 & & & 100.15 & & & 143.53 & \\
\hline LM statistic p-value & & 0.00 & & & 0.00 & & & 0.00 & \\
\hline Uncensored obs. & & & 307 & & & 268 & & & 360 \\
\hline Likelihood & & & -4864.3 & & & -3974.0 & & & -5117.5 \\
\hline Wald test chi2(1) & & & 39.95 & & & 36.39 & & & 34.16 \\
\hline \multicolumn{10}{|c|}{ First stage estimates: Dep. Variable: Training expenditure, log } \\
\hline Rivals & & & $\begin{array}{l}0.090 * * \\
(0.04)\end{array}$ & & & $\begin{array}{l}0.081 * \\
(0.04)\end{array}$ & & & $\begin{array}{l}-0.013 \\
(0.03)\end{array}$ \\
\hline Global & & & $\begin{array}{l}-0.16^{*} \\
(0.09)\end{array}$ & & & $\begin{array}{l}-0.10 \\
(0.10)\end{array}$ & & & $\begin{array}{l}0.062 \\
(0.06)\end{array}$ \\
\hline
\end{tabular}




\begin{tabular}{|c|c|c|c|c|c|c|}
\hline Public & & $\begin{array}{l}-0.11 \\
(0.13) \\
\end{array}$ & & $\begin{array}{l}-0.22 \\
(0.15) \\
\end{array}$ & & $\begin{array}{l}0.01 \\
(0.08) \\
\end{array}$ \\
\hline Foreign & & $\begin{array}{l}0.16 \\
(0.13)\end{array}$ & & $\begin{array}{l}-0.20 \\
(0.14)\end{array}$ & & $\begin{array}{l}-0.11 \\
(0.08)\end{array}$ \\
\hline Cooperation & & $\begin{array}{l}0.46 * * * \\
(0.13)\end{array}$ & & $\begin{array}{l}0.49 \text { *** } \\
(0.15)\end{array}$ & & $\begin{array}{l}0.61 * * * * \\
(0.08)\end{array}$ \\
\hline Patents & & $\begin{array}{l}0.03 \\
(0.08)\end{array}$ & & $\begin{array}{l}0.05 \\
(0.08)\end{array}$ & & \\
\hline Scientists & & $\begin{array}{l}0.01 * * * \\
(0.01)\end{array}$ & & $\begin{array}{l}0.01 * * * \\
(0.01)\end{array}$ & & $\begin{array}{l}0.01 * * * \\
(0.01)\end{array}$ \\
\hline Small firm & & $\begin{array}{l}-0.30 \text { **** } \\
(0.09)\end{array}$ & & $\begin{array}{l}-0.39 \text { *** } \\
(0.10)\end{array}$ & & $\begin{array}{l}-0.19^{\text {**** }} \\
(0.06)\end{array}$ \\
\hline Large firm & & $\begin{array}{l}0.58 * * * \\
(0.10)\end{array}$ & & $\begin{array}{l}0.51 * * * \\
(0.11)\end{array}$ & & $\begin{array}{l}0.13^{* *} \\
(0.06)\end{array}$ \\
\hline Firm's capacity & & $\begin{array}{l}0.24 * * * \\
(0.03)\end{array}$ & & $\begin{array}{l}0.31 \text { *** } \\
(0.04)\end{array}$ & & $\begin{array}{l}0.16^{* * * *} \\
(0.02)\end{array}$ \\
\hline Market info & & $\begin{array}{l}-0.03 \\
(0.03)\end{array}$ & & $\begin{array}{l}0.06 \\
(0.05)\end{array}$ & & $\begin{array}{l}0.05^{* * * *} \\
(0.02)\end{array}$ \\
\hline Constant & & $\begin{array}{l}0.18 \\
(0.30)\end{array}$ & & $\begin{array}{l}0.39 \\
(0.34)\end{array}$ & & $\begin{array}{l}0.18 \\
(0.20)\end{array}$ \\
\hline Industry 2 digit SIC controls & & Yes & & Yes & & Yes \\
\hline $\mathrm{F}$ - stat for instruments & 29.83 & & 37.24 & & 27.13 & \\
\hline
\end{tabular}

Source: UKIS- UK Innovation survey; BSD- Business Structure Database

Notes: *** - significant at $0.01 ; * *$ - significant at $0.05 ; *$ - significant at 0.1 . Standard errors are in parentheses robust to heteroskedasticity. HF index as a measure of competition intensity was taken out due to Top 6 sectors (SIC) control. Those sectors are introduced as $\operatorname{SIC}(92)$ classification.

Table A2: equation: Model 2 (panel data estimation)

\begin{tabular}{|c|c|c|c|c|c|c|c|}
\hline \multirow{3}{*}{ Dep. Var.: NPR in $000 \mathrm{~s} £, \log$} & \multicolumn{7}{|c|}{ Estimation method } \\
\hline & \multicolumn{4}{|c|}{ panel-data models } & \multicolumn{3}{|c|}{ Instrumental variables for panel-data models } \\
\hline & OLS & IMLE & $\mathrm{RE}$ & $\mathrm{FE}$ & $\mathrm{RE}$ & FE & EC2SLS RE \\
\hline Training & $\begin{array}{l}0.32 * * * \\
(0.04)\end{array}$ & $\begin{array}{l}0.32 * * * \\
(0.02)\end{array}$ & $\begin{array}{l}0.32 * * * \\
(0.02)\end{array}$ & $\begin{array}{l}0.25^{* * * *} \\
(0.03)\end{array}$ & $\begin{array}{l}3.77 * * * * \\
(0.34)\end{array}$ & $\begin{array}{l}3.81 * * * \\
(0.67)\end{array}$ & $\begin{array}{l}3.81 * * * \\
(0.40)\end{array}$ \\
\hline Rivals & $\begin{array}{l}-0.18 * * * \\
(0.05)\end{array}$ & $\begin{array}{l}-0.18 * * * \\
(0.04)\end{array}$ & $\begin{array}{l}-0.18 * * * \\
(0.04)\end{array}$ & $\begin{array}{l}-0.016 \\
(0.15)\end{array}$ & $\begin{array}{l}-0.40 * * * \\
(0.10)\end{array}$ & $\begin{array}{l}0.22 \\
(0.48)\end{array}$ & $\begin{array}{l}-0.37 * * * \\
(0.10)\end{array}$ \\
\hline
\end{tabular}




\begin{tabular}{|c|c|c|c|c|c|c|c|}
\hline Global & $\begin{array}{l}0.78 * * * \\
(0.12)\end{array}$ & $\begin{array}{l}0.78 * * * \\
(0.09)\end{array}$ & $\begin{array}{l}0.78 * * * \\
(0.09)\end{array}$ & $\begin{array}{l}0.36^{* *} \\
(0.15)\end{array}$ & $\begin{array}{l}0.95 * * * \\
(0.23)\end{array}$ & $\begin{array}{l}0.66 \\
(0.47)\end{array}$ & $\begin{array}{l}0.90 * * * \\
(0.22)\end{array}$ \\
\hline Public & $\begin{array}{l}0.30 * * * \\
(0.08)\end{array}$ & $\begin{array}{l}0.30 * * \\
(0.12)\end{array}$ & $\begin{array}{l}0.30 * * \\
(0.12)\end{array}$ & & $\begin{array}{l}0.55^{*} \\
(0.33)\end{array}$ & & $\begin{array}{l}0.57 * \\
(0.30)\end{array}$ \\
\hline Foreign & $\begin{array}{l}-0.22 \\
(0.19)\end{array}$ & $\begin{array}{l}-0.22 \\
(0.14)\end{array}$ & $\begin{array}{l}-0.22 \\
(0.14)\end{array}$ & & $\begin{array}{l}-0.15 \\
(0.32)\end{array}$ & & $\begin{array}{l}-0.15 \\
(0.29)\end{array}$ \\
\hline Cooperation & $\begin{array}{l}2.32 * * * \\
(0.23)\end{array}$ & $\begin{array}{l}2.31 \text { *** } \\
(0.14)\end{array}$ & $\begin{array}{l}2.32 * * * \\
(0.14)\end{array}$ & $\begin{array}{l}1.89 * * * \\
(0.17)\end{array}$ & $\begin{array}{l}0.072 \\
(0.38)\end{array}$ & $\begin{array}{l}0.18 \\
(0.56)\end{array}$ & $\begin{array}{l}0.15 \\
(0.40)\end{array}$ \\
\hline Patents & $\begin{array}{l}1.27 * * * \\
(0.14)\end{array}$ & $\begin{array}{l}1.25^{* * * *} \\
(0.10)\end{array}$ & $\begin{array}{l}1.27 * * * \\
(0.10)\end{array}$ & $\begin{array}{l}0.62 * * * * \\
(0.11)\end{array}$ & $\begin{array}{l}0.92 * * * \\
(0.24)\end{array}$ & $\begin{array}{l}0.38 \\
(0.34)\end{array}$ & $\begin{array}{l}1.01 * * * \\
(0.20)\end{array}$ \\
\hline Scientists & $\begin{array}{l}0.12 * * * \\
(0.01)\end{array}$ & $\begin{array}{l}0.12 * * * \\
(0.01)\end{array}$ & $\begin{array}{l}0.12 * * * \\
(0.01)\end{array}$ & $\begin{array}{l}0.12 * * * \\
(0.02)\end{array}$ & $\begin{array}{l}-0.15 * * * \\
(0.04)\end{array}$ & $\begin{array}{l}-0.01 \\
(0.06)\end{array}$ & $\begin{array}{l}-0.11^{* * * *} \\
(0.03)\end{array}$ \\
\hline Small firm & $\begin{array}{l}0.24 * * * \\
(0.08)\end{array}$ & $\begin{array}{l}0.23 * * * \\
(0.09)\end{array}$ & $\begin{array}{l}0.24 * * * \\
(0.09)\end{array}$ & $\begin{array}{l}-0.022 \\
(0.22)\end{array}$ & $\begin{array}{l}1.25 * * * \\
(0.24)\end{array}$ & $\begin{array}{l}-0.52 \\
(0.78)\end{array}$ & $\begin{array}{l}1.02 * * * \\
(0.20)\end{array}$ \\
\hline Large firm & $\begin{array}{l}0.030 \\
(0.12)\end{array}$ & $\begin{array}{l}0.030 \\
(0.10)\end{array}$ & $\begin{array}{l}0.030 \\
(0.10)\end{array}$ & $\begin{array}{l}-0.068 \\
(0.33)\end{array}$ & $\begin{array}{l}-1.28 * * * \\
(0.28)\end{array}$ & $\begin{array}{l}-0.76 \\
(1.30)\end{array}$ & $\begin{array}{l}-1.05 * * * \\
(0.21)\end{array}$ \\
\hline Year dummy CIS5 & $\begin{array}{l}-0.28 * * * \\
(0.07)\end{array}$ & $\begin{array}{l}-0.28 * * * \\
(0.07)\end{array}$ & $\begin{array}{l}-0.28 * * * \\
(0.07)\end{array}$ & $\begin{array}{l}-0.27 \text { *** } \\
(0.07)\end{array}$ & $\begin{array}{l}-0.12 \\
(0.21)\end{array}$ & $\begin{array}{l}-0.33 \\
(0.25)\end{array}$ & $\begin{array}{l}-0.14 \\
(0.19)\end{array}$ \\
\hline Year dummy CIS6 & $\begin{array}{l}0.01 \\
(0.07)\end{array}$ & $\begin{array}{l}0.01 \\
(0.07)\end{array}$ & $\begin{array}{l}0.01 \\
(0.07)\end{array}$ & $\begin{array}{l}-0.16^{* *} \\
(0.07)\end{array}$ & $\begin{array}{l}2.38 * * * \\
(0.31)\end{array}$ & $\begin{array}{l}2.00 \text { *** } \\
(0.50)\end{array}$ & $\begin{array}{l}2.20 * * * * \\
(0.24)\end{array}$ \\
\hline Constant & $\begin{array}{l}1.11 * * * \\
(0.32)\end{array}$ & $\begin{array}{l}1.12 * * * \\
(0.31)\end{array}$ & $\begin{array}{l}1.11^{* * *} \\
(0.31)\end{array}$ & $\begin{array}{l}0.87 \\
(0.96)\end{array}$ & $\begin{array}{l}-0.92 \\
(0.81)\end{array}$ & $\begin{array}{l}-3.37 \\
(3.16)\end{array}$ & $\begin{array}{l}-0.60 \\
(0.74)\end{array}$ \\
\hline Industry 2 digit SIC controls & Yes & Yes & Yes & Yes & Yes & Yes & Yes \\
\hline Obs. & 11653 & 11653 & 11653 & 11653 & 5344 & 5344 & 5013 \\
\hline Sigma u & 1.56 & 1.64 & 1.56 & 2.44 & 2.40 & 5.29 & 2.40 \\
\hline Sigma e & 2.93 & 2.93 & 2.93 & 2.93 & 5.72 & 5.72 & 5.72 \\
\hline Rho & 0.22 & 0.24 & 0.22 & 0.41 & 0.15 & 0.46 & 0.15 \\
\hline chi2 & 745.414 & 1508.95 & 1740.58 & & 468.1 & 706.8 & 468.1 \\
\hline$F_{-} f$ & & & & 1.91 & & 0.55 & \\
\hline Chibar2 & & 589.49 & & & & & \\
\hline
\end{tabular}

Source: UKIS- UK Innovation survey; BSD- Business Structure Database

Notes: *** - significant at $0.01 ; * *$ - significant at 0.05 ; * significant at 0.1 Standard errors are in parentheses robust to heteroskedasticity. Note: Panel data estimation models: OLS (Pooled OLS)- , FE (Fixed) -, RE random-effects, and

IMLE (Iterative maximum likelihood estimation) models; EC2SLS RE (Baltagi's EC2SLS random-effects estimator). F_f - Ftest that all $\mathrm{u}_{-} \mathrm{i}=0$ - rejected marginally at $10 \%$ revel for the panel data estimation and did not rejected for the instrumented paneldata models. Chibar2 is a Likelihood-ratio test of Sigma $u=0$ rejected at $1 \%$ level in favour of random effects. Hausman test (HT) chi2=171, signalling the endogeneity problem between the regressors and residuals in the model. This is also true for the 
instrumented regression (column (5-7) when two Hausman tests were performed: fixed effects vs. random effects estimator and fixed effects vs. Baltagi random effects estimators. Both HT reject the exogeneity of RE with the chi2=31.0 and EC2SLS RE with chi2=29.0. Although HT says that the error term is contaminated with endogeneity, Likelihood-ratio test of Sigma $u=0$ and F-test that all $\mathrm{u}_{-} \mathrm{i}=0$ both confirm the presence of random effects in the model. Note: Lack of market information as a constraint to innovation and the importance of increased capacity for production or service provision were used as instruments.

Table A3: Training -premium equation: Model 3 by firm age

\begin{tabular}{|c|c|c|c|c|}
\hline Dep. Var.: NPR in $000 \mathrm{~s} £, \log$ & Start-ups & Incumbents & Start-ups & Incumbents \\
\hline Estimation method & OLS & OLS & Baltagi RE & Baltagi RE \\
\hline Training & $\begin{array}{l}0.36^{* * *} \\
(0.14)\end{array}$ & $\begin{array}{l}0.32 * * * \\
(0.04)\end{array}$ & $\begin{array}{l}2.78 * * * \\
(0.55)\end{array}$ & $\begin{array}{l}3.32 * * * \\
(0.31)\end{array}$ \\
\hline Rivals & $\begin{array}{l}-0.097 \\
(0.12)\end{array}$ & $\begin{array}{l}-0.19 * * * \\
(0.05)\end{array}$ & $\begin{array}{l}0.042 \\
(0.23)\end{array}$ & $\begin{array}{l}-0.44 * * * \\
(0.10)\end{array}$ \\
\hline Global & $\begin{array}{l}1.27 * * * \\
(0.43)\end{array}$ & $\begin{array}{l}0.74 * * * \\
(0.13)\end{array}$ & $\begin{array}{l}1.22 * * \\
(0.59)\end{array}$ & $\begin{array}{l}0.95^{* * * *} \\
(0.22)\end{array}$ \\
\hline Public & $\begin{array}{l}0.49 * * \\
(0.23)\end{array}$ & $\begin{array}{l}0.26 * * * \\
(0.08)\end{array}$ & $\begin{array}{l}0.25 \\
(0.81)\end{array}$ & $\begin{array}{l}0.53 \\
(0.33)\end{array}$ \\
\hline Foreign & $\begin{array}{l}0.52 \\
(0.75)\end{array}$ & $\begin{array}{l}-0.27 \\
(0.19)\end{array}$ & $\begin{array}{l}1.00 \\
(1.00)\end{array}$ & $\begin{array}{l}-0.27 \\
(0.32)\end{array}$ \\
\hline Cooperation & $\begin{array}{l}2.58 * * * \\
(0.58)\end{array}$ & $\begin{array}{l}2.28 * * * \\
(0.25)\end{array}$ & $\begin{array}{l}1.72 * * \\
(0.75)\end{array}$ & $\begin{array}{l}0.25 \\
(0.36)\end{array}$ \\
\hline Patents & $\begin{array}{l}1.48^{* * *} \\
(0.46)\end{array}$ & $\begin{array}{l}1.25^{* * *} \\
(0.14)\end{array}$ & $\begin{array}{l}1.86^{* * * *} \\
(0.59)\end{array}$ & $\begin{array}{l}0.87 \text { *** } \\
(0.23)\end{array}$ \\
\hline \multirow[t]{2}{*}{ Scientists } & $0.15 * * *$ & $0.12 * * *$ & -0.038 & $-0.10 * * *$ \\
\hline & $(0.05)$ & $(0.01)$ & $(0.09)$ & $(0.04)$ \\
\hline Small firm & $\begin{array}{l}0.39 \\
(0.26)\end{array}$ & $\begin{array}{l}0.20 * * \\
(0.09)\end{array}$ & $\begin{array}{l}2.06 * * * \\
(0.55)\end{array}$ & $\begin{array}{l}1.01 \text { *** } \\
(0.24)\end{array}$ \\
\hline Large firm & $\begin{array}{l}-0.14 \\
(0.38)\end{array}$ & $\begin{array}{l}0.065 \\
(0.12)\end{array}$ & $\begin{array}{l}1.27 * \\
(0.77)\end{array}$ & $\begin{array}{l}-1.24 * * * \\
(0.29)\end{array}$ \\
\hline Year dummy CIS5 & $\begin{array}{l}-0.47 * * \\
(0.22)\end{array}$ & $\begin{array}{l}-0.25 * * * \\
(0.07)\end{array}$ & $\begin{array}{l}-0.88 \\
(0.57)\end{array}$ & $\begin{array}{l}-0.10 \\
(0.20)\end{array}$ \\
\hline
\end{tabular}




\begin{tabular}{|l|l|l|l|l|} 
Year dummy CIS6 & $\begin{array}{l}-0.12 \\
(0.19)\end{array}$ & $\begin{array}{l}0.027 \\
(0.07)\end{array}$ & $\begin{array}{l}0.81 \\
(0.58)\end{array}$ & $\begin{array}{l}2.17 * * * \\
(0.29)\end{array}$ \\
\hline Constant & $\begin{array}{l}0.47 \\
(0.90)\end{array}$ & $\begin{array}{l}1.22^{* * *} \\
(0.35)\end{array}$ & $\begin{array}{l}-2.85 \\
(1.81)\end{array}$ & $\begin{array}{l}-0.21 \\
(0.81)\end{array}$ \\
\hline Industry 2 digit SIC controls & Yes & Yes & Yes & Yes \\
\hline Obs. & 1209 & 10444 & 520 & 4824 \\
\hline Sigma u & 1.41 & 1.57 & 0 & 2.90 \\
\hline Sigma e & 2.90 & 2.93 & 6.67 & 5.58 \\
\hline Rho & 0.19 & 0.22 & 0 & 0.21 \\
\hline chi2 & 180.10 & 635.15 & 115.33 & 454.49 \\
\hline
\end{tabular}

Source: UKIS- UK Innovation survey; BSD- Business Structure Database

Notes: *** - significant at $0.01 ; * *$ - significant at 0.05 ; * significant at 0.1 Standard errors are in parentheses robust to heteroskedasticity. Note: Lack of market information as a constraint to innovation and the importance of increased capacity for production or service provision were used as instruments.

\section{Appendix B}

Table B1. Early stage literature review of the returns to training for firm performance in management and innovation literature.

\begin{tabular}{|c|c|c|c|c|c|}
\hline Study & Dataset & Method & Performance measure & $\begin{array}{l}\text { Data type/ Sample } \\
\text { size }\end{array}$ & Results \\
\hline $\begin{array}{l}\text { Hansson } \\
\text { (2007) }\end{array}$ & The Cranet survey & OLS, Probit & $\begin{array}{l}\text { (1) the top } 10 \text { per } \\
\text { cent; } \\
\text { (2) the upper half; or } \\
\text { (3) the lower half of all } \\
\text { firms in the sector re: } \\
\text { profitability. }\end{array}$ & $\begin{array}{l}5,824 \text { private-sector } \\
\text { firms in } 26 \text { countries }\end{array}$ & $\begin{array}{l}\text { Positive relationship between the } \\
\text { number of employees receiving } \\
\text { training and being in top } 10 \text { per } \\
\text { cent of profitability among other } \\
\text { firms in the same sector. }\end{array}$ \\
\hline $\begin{array}{l}\text { Bishop } \\
\text { (1991) }\end{array}$ & EOPP & & Productivity rating & 2594 firms & $\begin{array}{l}\text { ROI on } 100 \text { hours of new hire } \\
\text { training ranged from } 11 \% \text { to } \\
38 \% \text {. }\end{array}$ \\
\hline $\begin{array}{l}\text { Holzer et al. } \\
(1993)\end{array}$ & $\begin{array}{l}\text { Survey sent } r \\
\text { Michigan } \\
\text { applying for } \text { firms } \\
\text { training grants }\end{array}$ & $\begin{array}{l}\text { Fixed } \\
\text { effects }\end{array}$ & Scrap rates & 157 firms & $\begin{array}{l}\text { Doubling of worker training } \\
\text { reduces scrap rates by } 7 \% \text {; this is } \\
\text { worth } \$ 15,000 \text {. }\end{array}$ \\
\hline Bartel (1994) & $\begin{array}{ll}\text { Columbia } & \text { HR } \\
\text { Survey (1986) } & \end{array}$ & OLS, Probit & $\begin{array}{lll}\begin{array}{l}\text { Value } \\
\text { worker }\end{array} & \text { added } & \text { per } \\
\end{array}$ & $\begin{array}{l}155 \text { US enterprises } \\
\text { in } 1986\end{array}$ & $\begin{array}{l}\text { Firms operating at less than their } \\
\text { expected labour productivity in } \\
1983 \text { implemented training }\end{array}$ \\
\hline
\end{tabular}




\begin{tabular}{|c|c|c|c|c|c|}
\hline & & & & & $\begin{array}{l}\text { programmes which resulted in } \\
\text { them achieving higher } \\
\text { productivity growth between } \\
1983 \text { and } 1986 \text {, by } 6 \% \text { per year }\end{array}$ \\
\hline $\begin{array}{l}\text { Black and } \\
\text { Lynch (1996) }\end{array}$ & $\begin{array}{lr}\text { EQW } & \text { national } \\
\text { Employers } & \text { survey } \\
(1993) & \end{array}$ & & Net sales & $\begin{array}{l}\text { US National } \\
\text { Employers' Survey } \\
\text { for 1994, } 617 \text { firms }\end{array}$ & $\begin{array}{l}\text { Firms' investment in human } \\
\text { capital in terms of training is } \\
\text { positively related to productivity, } \\
\text { but no effect on the } \\
\text { establishment-specific residual }\end{array}$ \\
\hline $\begin{array}{l}\text { Black and } \\
\text { Lynch (2001) }\end{array}$ & $\begin{array}{lr}\text { EQW } & \text { national } \\
\text { Employers } & \text { survey } \\
(1987-1993) & \end{array}$ & & Productivity & $\begin{array}{l}\text { panel data for } 1987 \\
\text { to } 1993\end{array}$ & $\begin{array}{l}\text { Number of workers trained in a } \\
\text { firm is not statistically } \\
\text { significantly } \\
\text { linked to productivity. }\end{array}$ \\
\hline $\begin{array}{l}\text { Barrett and } \\
\text { O'Connell } \\
\text { (2001) }\end{array}$ & $\begin{array}{l}\text { Surveys of } \\
\text { enterprises in Ireland } \\
\text { in 1993 and 1996-7 }\end{array}$ & & Productivity & $\begin{array}{l}\text { Surveys of } \\
\text { enterprises in Ireland } \\
\text { in } 1993 \text { and 1996-7 }\end{array}$ & $\begin{array}{l}\text { General and all training is } \\
\text { positively related to productivity; } \\
\text { specific training has no } \\
\text { significant impact. }\end{array}$ \\
\hline $\begin{array}{l}\text { Cassidy et al. } \\
\text { (2005) }\end{array}$ & $\begin{array}{ll}\text { Total } & \text { factor } \\
\text { Productivity } & \end{array}$ & $\begin{array}{l}\text { Panel data } \\
\text { fixed } \\
\text { effects } \\
\text { estimation }\end{array}$ & $\begin{array}{ll}\text { Total } & \text { Factor } \\
\text { Productivity } & \end{array}$ & $\begin{array}{l}\begin{array}{l}\text { Foreign-owned and } \\
\text { indigenous }\end{array} \\
\text { manufacturing with } \\
>10 \text { workers from } \\
1999 \text { until } 2002\end{array}$ & $\begin{array}{l}\text { Plants engaged in training have a } \\
\text { TFP advantage of } 0.3 \\
\text { percent, ceteris paribus }\end{array}$ \\
\hline $\begin{array}{l}\text { Tan and Batra } \\
\text { (1997) }\end{array}$ & World Bank survey & $\begin{array}{ll}\text { OLS } & \text { and } \\
\text { probit }\end{array}$ & Log of Value added & $\begin{array}{l}300-56,000 \text { firms by } \\
\text { country }\end{array}$ & $\begin{array}{l}\text { Predicted training has positive } \\
\text { effect on value added; effects } \\
\text { range from } 2.8 \% \text { to } 71 \% \text { per year }\end{array}$ \\
\hline $\begin{array}{l}\text { Thornhill } \\
\text { (2006) }\end{array}$ & $\begin{array}{l}\text { Survey of Canadian } \\
\text { Manufacturing firms }\end{array}$ & $\begin{array}{l}\text { Weighted } \\
\text { Heckman } \\
\text { regression, } \\
\text { Logit, OLS }\end{array}$ & $\begin{array}{l}\text { Innovation; } r e v e n u e \\
\text { growth for high } \\
\text { technology and low } \\
\text { technology } \\
\text { separately }\end{array}$ & 845 firms & $\begin{array}{l}\text { Training is not statistically } \\
\text { significant for either group; } \\
\text { Training positive significant for } \\
\text { innovation }\end{array}$ \\
\hline $\begin{array}{l}\text { Huselid } \\
\text { (1995) }\end{array}$ & $\begin{array}{lr}1992 & \text { survey of } \\
\text { human } & \text { resource } \\
\text { practices } & \end{array}$ & $\begin{array}{l}\text { OLS, Fixed } \\
\text { effects }\end{array}$ & $\begin{array}{l}\text { Tobin's Q and gross } \\
\text { rate of return on capital }\end{array}$ & 968 firms & $\begin{array}{l}\text { High performance practices had } \\
\text { significant effect in cross- } \\
\text { sections but disappeared in the } \\
\text { fixed effects study }\end{array}$ \\
\hline $\begin{array}{l}\text { Giovannetti } \\
\text { and Piga } \\
(2017)\end{array}$ & Innovation surveys & Tobit & $\begin{array}{l}\text { Product, process } \\
\text { innovation }\end{array}$ & $>20000$ firms & $\begin{array}{l}\text { Training and R\&D positively } \\
\text { affect innovation in products and } \\
\text { services, while networks } \\
\text { facilitate this relationship }\end{array}$ \\
\hline Bassi (1984) & $\begin{array}{l}\text { Continuous } \\
\text { Longitudinal } \\
\text { Manpower survey } \\
(1975-1978) \\
\end{array}$ & $\begin{array}{l}\text { Fixed } \\
\text { effects/rand } \\
\text { om effects }\end{array}$ & Worker earnings & $\begin{array}{l}\text { Earnings of white } \\
\text { and non-white males } \\
\text { and females }\end{array}$ & $\begin{array}{l}\text { While women are found to } \\
\text { benefit significantly from } \\
\text { manpower training programs, no } \\
\text { such effect was found for men }\end{array}$ \\
\hline
\end{tabular}

\section{Source: Authors}

